University of Michigan Law School

University of Michigan Law School Scholarship Repository

Articles

Faculty Scholarship

1989

\title{
Accommodation and Satisfaction: Women and Men Lawyers and the Balance of Work and Family
}

David L. Chambers

University of Michigan Law School, dcham@umich.edu

Available at: https://repository.law.umich.edu/articles/852

Follow this and additional works at: https://repository.law.umich.edu/articles

Part of the Law and Gender Commons, Law and Society Commons, and the Legal Profession Commons

\section{Recommended Citation}

Chambers, David L. "Accommodation and Satisfaction: Women and Men Lawyers and the Balance of Work and Family." Law \& Soc. Inquiry 14 (1989): 251-87.

This Article is brought to you for free and open access by the Faculty Scholarship at University of Michigan Law School Scholarship Repository. It has been accepted for inclusion in Articles by an authorized administrator of University of Michigan Law School Scholarship Repository. For more information, please contact mlaw.repository@umich.edu. 


\section{Accommodation and Satisfaction: Women and Men Lawyers and the Balance of Work and Family}

David L. Chambers

This study of graduates of the University of Michigan Law School from the late 1970s reports on the differing ways that women and men have responded to the conflicting claims of work and family. It finds that women with children who have entered the profession have indeed continued to bear the principal responsibilities for the care of children, but it also finds that these women, with all their burdens, are more satisfied with their careers and with the balance of their family and professional lives than other women and than men.

Women first entered the legal profession in large numbers in the 1970s. The same movement that brought them into the profession also sought to deliver messages to men that they ought to participate more in the raising of children. How, over the decade that has followed, have men and women lawyers responded to the multiple roles of home and work? How satisfied are they with the balance they have struck and with their careers overall?

This article draws on data from a study conducted at three points in time of the graduates in the late 1970s of the University of Michigan Law School. The study has reached some conclusions that might be expected and others that might not. Women lawyers who are parents continue to

David L. Chambers is a professor of law at the University of Michigan Law School. LL.B. 1965, Harvard University.

The research reported in this article was supported by the American Bar Foundation and the University of Michigan Law School. Throughout the study, the author has been aided by Terry $\mathrm{K}$. Adams of the University of Michigan's Institute for Social Research and by Mary Louise Lowther, who has overseen the administration of the law school's Alumni Survey. 
bear substantially greater burdens for the care of children than men. Men, on the other hand, have altered their careers very little in order to participate in families. And yet, despite the pressures of their multiple roles, the Michigan women in general and those with children in particular have been satisfied with their careers and generally satisfied with the balance of their family and professional lives. In fact, five years after law school, and again seven to ten years after law school, the women with children report themselves, as a group, somewhat more satisfied with their careers and with the balance of their family and professional lives than women without children and than men, with or without children, report themselves to be.

After a review of the literature on women's and, to a lesser extent, men's responses to multiple demands of work and family, the article describes the Michigan study's design and the general patterns of work and family of the Michigan women and men. It then turns to describing, in some detail, the different ways women and men have balanced their family and professional lives and the differing degrees of satisfaction women and men, with and without children, express. The article ends with an attempt to understand why the women with children express the high degrees of satisfaction that they do. One of the women surveyed referred to "the psychological baggage" she carried because she was a "woman and a wife and a mother and a fulltime lawyer." The baggage she carried is heavy. The paradox we seek to explore is why she and so many others with the same baggage seem more contented than those without it.

\section{MULTIPLE ROLES AND WORK SATISFACTION: A REVIEW OF RESEARCH}

\section{A. The Work Experience of Women with Children}

The substantial body of research on women who work outside the home ${ }^{1}$ nearly all starts with a common, unassailable observation - that women, even when holding a job, bear a heavier burden than men for the care of small children. ${ }^{2}$ Within dual-career families, men spend only slightly more time performing child-tending and housekeeping tasks than do men in families in which the wife holds no job outside the home. ${ }^{3}$

1. See, e.g., F. Crosby, ed., Spouse, Parent, Worker: On Gender and Multiple Roles (1987) ("Crosby, Spouse"); K. Gerson, Hard Choices: How Women Decide About Work, Career and Motherhood (1985) ("Gerson, Hard Choices"); R. Rapoport \& R. Rapoport, eds., Working Couples (1978); R. Smuts, Women and Work in America (1979); L. Tilly \& J. Scott, Women, Work and Family (1978).

2. Gerson's book offers an incisive critique of the various explanations why women have ended up in their present position with regard to childtending. Hard Choices 23-42. (1985).

3. P. Roos, Gender and Work (1985); Pleck, Working Wives/Working Husbands 27-51 
Simply being a parent of young children imposed stresses. Mothers of young children, whether or not they work outside the home, are more likely than other women to feel that life is hard, that they are tied down, that they are always rushed, and that they may suffer a nervous breakdown. ${ }^{4}$ Fathers of young children report comparable stress in their roles as provider and husband. 5

The mother who works outside the home typically faces additional stress that men face less or in different ways or not at all. The working mother's conflicts take at least three forms: conflicts in time demands; conflicts growing out of strain (in the sense that the emotional or energy demands in one setting leave the parent without the emotional reserve to respond adequately in the other); and conflicts in behavioral expectations (in the sense of difficulties in adjusting from the aggressive demeanor expected in some jobs to the nurturant demeanor needed in the parenting role). ${ }^{6}$ Both men and women find it difficult to keep the spheres of work and family life separate, but men tend to permit work to intrude on family life, whereas women tend to permit (or feel forced to permit) family to intrude on work. ${ }^{7}$

How do women who have children respond to the demands of these multiple roles? Social scientists have offered two competing theories. Much writing, especially before the 1980 s, treated multiple role responsibilities for men and women as wholly negative in their effects. ${ }^{8}$ Some studies found that when faced with stress, working mothers in particular were more likely than other women to report depression, anxiety, chronic fatigue, and panic. ${ }^{9}$ The strains of parenting and work are thought to be particularly severe for divorced and unmarried women raising children on their own. ${ }^{10}$

In the recent past, however, some researchers on women in the labor force have put forth a different view, finding that many women, including many mothers, respond to multiple roles and their demands with satisfac-

4. See A. Campbell, P. Converse, \& W. Rodgers, The Quality of American Life: Perceptions, Evaluations, and Satifactions 404-5 (1976) ("Campbell, Converse, \& Rodgers, Quality").

5. Id.

6. See the useful summary in J. Greenhaus \& N. Beutell, "Sources of Conflict between Work and Family Roles," Acad. Mgmt. Rev., Jan. 1985, at 10; see also J. Pleck, G. Staines, \& L. Lang, "Conflicts between Work and Family Life," U.S. Dept. of Labor, Monthly Lab. Rev., March 1980, at 29, 30.

7. See J. Pleck, "The Work-Family Role System," 24 Soc. Probs. 417 (1977).

8. See, e.g., W. Goode, "A Theory of Role Strain," 25 Am. Soc. Rev. 483 (1960).

9. See review of literature in Project, "Gender, Legal Education, and the Legal Profession: An Empirical Study of Stanford Law Students and Graduates," 40 Stan. L. Rev. 1209, 1229-30 (1988).

10. J. Wallerstein \& J. Kelly, Surviving the Breakup: How Children and Parents Cope with Divorce (1980); Hetherington, Cox, \& Cox, "Stress and Coping: A Focus on Women," in J. Gullahorn, ed., The Psychology of Women 95 (1979). 
tion rather than dismay. ${ }^{11}$ The theme of a recent set of essays on gender and multiple roles is that "not the multiplicity of roles, but the paucity of roles, has a deleterious effect on individual well-being." 12 Multiple roles, it is argued, provide satisfaction by offering variety and relief, by permitting a sense of mastery, and by providing some broader perspective on the problems in any one setting. They also, as one author adds, "provide legitimate excuses for failing to meet normal obligations in any one role. . . . [They] can buffer the individual against the consequences of role failure or loss."13

In the view of these recent writings, the challenging task for research is not to decide whether multiple roles cause harm or benefit but to identify the factors that explain why some persons react positively and some negatively to the demands of work and parenting. Among factors believed to contribute to higher satisfaction with multiple roles are the woman's preexisting sense of confidence or self-esteem, ${ }^{14}$ the woman's higher earnings, ${ }^{15}$ higher education, ${ }^{16}$ a diversity of social networks, ${ }^{17}$ a woman's perception of her job as important, ${ }^{18}$ equitable arrangements between spouses for domestic decision making and management, ${ }^{19}$ and a husband's supportive attitude toward his wife's career. ${ }^{20}$ Some outer limit must also exist on bearable demands from multiple roles. At some point, no matter how a woman feels about her job, the total hours demanded of her at work must almost certainly interfere with a sense of satisfaction with the balance of work and family.

What is the impact of multiple roles on women's, and particularly mothers', satisfaction with their work? In studying the Michigan men and women, we have wanted to understand and compare the career satisfaction of working women with children with that of other women and of men. Just as there is a large literature on working women and their satisfactions with their lives or their multiple roles, there is also a large literature on people's satisfaction with jobs and other domains of their lives.

Interpreting reports of satisfaction with any aspect of life is always

11. See R. Barnett, "Multiple Roles and Well-Being: A Study of Mothers of PreSchool Age Children," 1 Psychology Women Q. 175 (1982).

12. F. Crosby, ed., Spouse (cited in note 1).

13. P. Thoits, "Negotiating Roles," in Crosby, Spouse 11, 13.

14. U. Sekeran, "Factors Influencing the Quality of Life in Dual-Career Families," 56 J. Occupational Psychology 161 (1983).

15. Thoits, "Roles" at 11,17-18, and Steil \& Turetsky, "Marital Influence Levels and Symptomatology Among Wives," in Crosby, Spouse 74 ("Steil \& Turetsky").

16. Thoits, "Roles" at 18.

17. Id.

18. Steil \& Turetsky (cited in note 15 ).

19. Id.

20. Epstein, "Multiple Demands and Multiple Roles: The Conditions of Successful Management," in Crosby, Spouse ("Epstein, 'Demands' "); see also J. Greenhaus \& N. Beutell, "Sources of Conflict Between Work and Family Roles," Family Stud. Rev. Y.B. 299, 306 (1986). 
problematic. A person's expressed level of satisfaction with career (or life in general) is in large part a subjective measure of the difference between her aspirations (or expectations) and her achievements. A person with low expectations may report a higher degree of satisfaction than someone who has achieved more but also expected much more. ${ }^{21}$ Moreover, when asked about satisfaction, a person may well report the feelings of the moment. Despite all these problems, there is a substantial literature based on self-reports of satisfaction and a widespread acceptance that such reports measure some enduring self-perceptions. ${ }^{22}$

The many studies comparing women's and men's job satisfaction have typically found few differences, despite the many reasons for expecting women to be less satisfied. In their broad study of Americans' life satisfaction, Campbell, Converse, and Rodgers reported, with some perplexity: "There is practically no difference between women and men in average job satisfaction. This is an example of the discrepancy which may occur between objective conditions and subjective evaluation. Employed women hold jobs which on the average have lower status and lower pay than those of men, but they appear to be equally satisfied with them."23 Married women with college degrees reported especially high job satisfaction, as high as that reported by married men with college degrees, even though they too earned much less, on average, than the men. ${ }^{24}$ In general, single persons, both men and women, report lower satisfaction with their work than persons who are married. ${ }^{25}$

Fewer studies have compared the job satisfaction of women with young children with that of other women or with men. Nearly all find

21. Even two people with essentially the same aspirations and the same achievements may differ in their reports of satisfaction if they perceive differently the size of the gap between their aspirations and achievements or if they have different degrees of reluctance about expressing very high or very low satisfaction.

22. See, e.g., Campbell, Converse, \& Rogers, Quality (cited in note 4); see also P. Smith, L. Kendell, \& C. Hulin, The Measurement of Satisfaction in Work and Retirement (1969).

23. Campbell, Converse, and Rodgers, Quality 300-301. See also F. Crosby, "Job Satisfaction and Domestic Life," in M. Lee \& R. Kunango, Management of Work and Personal Life 41,43 (1984) ("Crosby, 'Job Satisfaction' ") ("Ever since researchers have kept records, they have found women workers to be subjectively content with objectively objectionable conditions."); Weaver, "Sex Differences in the Determinants of Job Satisfaction, 21 Acad. Mgmt. J. 265 (1978) (finding no differences and reporting ten other studies that found no differences). A few studies have found that women are as satisfied with their work as are men only if certain variables such as education, tenure, and job level are taken into account. See M. Kavanagh \& M. Halpern, "The Impact of Job Level and Sex Differences on the Relationship Between Life and Job Satisfaction," 20 Acad. Mgmt. J. 66 (1977).

24. Campbell, Converse, \& Rodgers, Quality 428,432 , reporting $72 \%$ of married, college-educated women and $67 \%$ of married, college-educated men very satisfied with their jobs.

25. Id; F. Crosby, Relative Deprivation and Working Women 12, 64-65 (1982) ("Crosby, Deprivation"). Crosby explains the higher satisfaction of married persons in part on the ground that "a happy home life prevents a person from brooding about problems at work." Id. at 159. 
women with children as satisfied with their jobs as other women and as men. ${ }^{26}$ Consistent with the new theory of the satisfactions from multiple roles, at least one study has found women with children generally more satisfied with their jobs than are other women. ${ }^{27}$

Why women in general and married women and mothers in particular are as satisfied with their work as are men, despite lower pay and prestige, has puzzled many commenters. Some of the explanation probably lies in women in general having lower expectations for achievement and a lower sense of entitlement to achieve. ${ }^{28}$ Mothers may have especially lowered expectations. On the other hand, the recent literature on the positive experience for women of mastery in multiple roles may also contribute to the explanation. ${ }^{29}$

\section{B. Work and Family Issues for Lawyers}

When the legal profession was almost entirely male, almost no one thought of examining the tensions between work and family. ${ }^{30}$ As the numbers of women in the legal profession have increased, now reaching about $40 \%$ of students finishing law school each year, interest has grown in the problems of balancing family and work, ${ }^{31}$ although virtually all this

26. See, e.g., Weaver, 21 Acad. Mgmt. J. 265 (drawing on three national samples at different times and finding that, on average, neither working women with "babies" nor working women with "preteens" reported lower job satisfaction than other working women); Bersoff \& Crosby, "Job Satisfaction and Family Status," 10 Personality \& Soc. Psychology Bull. 79 (1984) (drawing on several large national surveys conducted in the 1970s and early 1980s and finding no differences between married men and women with and without children-both were highly (and roughly equally) satisfied with their work. They did, however, find married men and women more satisfied with their work than single men and women.) But see R. Quinn, G. Staines, \& M. McCollough, Job Satifaction: Is There a Trend? (U.S. Dept. of Labor, 1974) (finding working women with preschool children less satisfied with their jobs than other women).

27. Crosby, "Job Satisfaction" at 43 (cited in note 23).

28. See Crosby, Deprivation, 16-23 (cited in note 25).

29. Id at $158-59$.

30. The Michigan Alumni Survey, in its early years, asked questions about work and family but only of the few women graduates. The survey instrument in the years before 1976 asked women: "If married, how does your husband feel about your career?" "How have you managed to combine work with family responsibilities?" Women but not men were asked how many children they had. In 1976 the questionnaire was revised to ask essentially the same questions of men. The questionnaire was revised again in 1981 into the form we have been reporting here.

31. The first major studies of women lawyers were J. White, "Women in the Law," 68 Mich. L. Rev. 1051 (1967), and Cynthia Fuchs Epstein, Women in Law (1981). For a current review and critique of the literature on women as lawyers in the Unired States and elsewhere, see C. Menkel-Meadow, "Feminization of the Legal Profession: The Comparative Sociology of Women Lawyers," in Richard Abel \& Phillip Lewis, Lawyers in Society: Comparative Theories 196 (1989) ("Menkel-Meadow, 'Feminization' "). For another review of the writing about the woman as professional (particularly the woman as lawyer) in the United States, see D. Rhode, "Perspectives on Professional Women," 40 Stan. L. Rev. 1163 (1988). 
literature has addressed the problems for women, not men.

Some recent research has examined the problems of work and family of women lawyers in the 19th century. Before 1900 , most of the few women admitted to the bar either never married at all or married an attorney and worked in his office as stenographer, clerk, and associate. ${ }^{32}$ Into the latter half of the 20th century, the numbers of women lawyers remained very small, and although far fewer of these women worked in their husbands' offices, women who had children commonly stopped working as lawyers altogether or shifted to part-time work. In his 1967 study of a national sample of women who graduated from American law schools between 1956 and 1965, James J. White found only $45 \%$ of married women with children working full time. The remainder were distributed roughly equally between part-time work and not working outside the home at all.33 American women who did practice law, full time or part time, often chose or were assigned to estate work or similar substantive areas that were considered "appropriate" for women and consistent with childtending responsibilities. ${ }^{34}$

Recent writing about lawyers with young children focuses primarily on the difficulties for women of meeting the conflicting demands of practice and childrearing. A high proportion of such women, though somewhat fewer than in the past, work part time or drop out of the labor force. ${ }^{35}$ Many journalistic accounts about women with children in large law firms depict the travails of working full time, striving simultaneously to raise children and compete for partnership. ${ }^{36}$ The accounts emphasize discouragement, frustration, and fatigue. They describe techniques women

32. V. Drachman, "My "Partner" in Law and Life': Marriage in the Lives of Women Lawyers in Lare 19th- and Early 20th-Century America," in this issue of Law \& Social Inquiry. For a popular history of women in the legal profession, see K. Morello, The Invisible Bar: The Woman Lauyer in America (1986).

33. White, 68 Mich. L. Rev. 1065; Epstein similarly found fewer than half of the mothers working full time among her sample of women attorneys interviewed in the 1970s. Much the same pattern is reported in Great Britain today. A recent report of the Law Society in Great Britain found that of women lawyers with children who were admitted to practice in 1977 , only $33 \%$ were working full time, $40 \%$ were working part time, and $27 \%$ were not working. Equal in the Law, Report of the Working Party on Women's Careers (1988).

34. White, 68 Mich. L Rev. at 1063. Men were more likely than women to handle litigation. Epstein found women somewhat more likely to handle estate and "blue sky" work. Epstein, Women in Law at xx.

35. See J. Abramson \& B. Franklin, Where Are They Now? The Story of the Women of Harvard Law 301-7 (1974) ("Abramson \& Franklin, Where Are They Now?"); Project, 40 Stan. L. Rev. 1209 (cited in note 9) (reporting 22\% of women and $13 \%$ of men working 140 or fewer hours each month).

36. See, e.g., J. Abramson, "For Women Lawyers, an Uphill Struggle," N.Y. Times (Mag.), March 6, 1988, at 36 (women in a large New York law firm); Blodgett, "Whatever Happened to the Class of 1981?" ABA J., June 1, 1988, at 56 (six women who began at a Chicago law firm in 1981 and have all since left); Abramson \& Franklin, Where Are They Now?; see also Yates \& Goldberg, "Superwoman Is Alive and Well," ABA J., May 15, 1987, at $18,20$. 
use to cope with the conflicting demands-bringing babies to the office at feeding time or on out-of-town trips with a babysitter in a hotel; juggling trials, ballet lessons, and appointments with the pediatrician. Few convey that women with young children find careers in practice particularly satisfying. ${ }^{37}$

Of the recent writing, Cynthia Fuchs Epstein's is probably the most positive in tone. In her 1981 study, Women in Law, Epstein reported that many women attorneys find satisfaction in successfully meeting the demands of family and work: "Good lawyers are problem solvers. Many of those interviewed attacked the problems of managing home and work in the same direct, matter-of-fact way they managed their offices."38 In a more recent essay, Epstein expands on these views and argues that current writers' emphasis on role strain for women with children results not alone from sympathy for women's difficulties but also "from the fact that some people feel threatened by the vitality and productivity of working women with accomplishments in different life roles." 39

Few studies have attempted to measure and compare job satisfaction of women and men attorneys. Until this study, none has compared the job satisfaction of women with children with that of other women. The one study that compares a large national sample of women and men attorneys, conducted in the early 1980 s by the American Bar Association, found high levels of job dissatisfaction generally among young lawyers in private practice and especially high dissatisfaction among women. Nineteen percent of male and $40 \%$ of female "junior" associates in law firms said they were dissatisfied with their jobs. ${ }^{40}$ The study did not inquire about parenting status. Most of the reasons that women were dissatisfied-that their job atmosphere was not warm, that advancement was not determined by the quality of their work, that they had no control over the cases they handle-would seem to apply equally to women who are and are not mothers, although one reason-that they have virtually no time to themselves-has particular relevance to mothers.

A recent study of women and men graduates of Stanford Law School of all age ranges found that both men and women experience stress but that women were more likely than men to report nightmares, loneliness, and depression. ${ }^{41}$ On the other hand, in contrast to the ABA study, the Stanford study found that both men and women were quite satisfied with

37. See the review of various writings in Rhode, 40 Stan. L. Rev. at 1181-87 (cited in note 31 ).

38. Epstein, Women in Law 362 (cited in note 31).

39. Epstein, "Demands" at 23 (cited in note 20).

40. R. Hirsch, "Are You on Target?" Barrister, Winter 1985, at 17, 19, a study sponsored by the Young Lawyers Division of the American Bar Association. Hirsch also found that $13 \%$ of male "senior" associates and $25 \%$ of female "senior" associates were dissatisfied.

41. Project, 40 Stan. L. Rev. 1209, 1252 (cited in note 9). 
their present jobs, and that, few of the women or men expected to change jobs in the near future. ${ }^{42}$ The study also found no differences between men and women in their degree of certainty about meeting career goals. ${ }^{43}$

\section{The Hypotheses of the Michigan Study}

In analyzing the data from the survey of the recent Michigan graduates, we hypothesized that women would report devoting more effort to family and children than would men lawyers in comparable positions and that women would make more adjustments than men to accommodate the conflicting demands of family and work. We were less certain what we would find about women's and men's satisfaction with the balance of their family and professional lives or with their careers overall. Two contrasting findings seemed possible. With regard to both sorts of satisfaction, recent writings suggested that the highly educated, high-earning women we studied might be well contented and research on job satisfaction suggested that most women and men workers, with and without children, would be highly satisfied with their jobs.

Nonetheless, the negative findings of the ABA survey and the somber tone of most of the popular writing about women lawyers who are mothers suggested the possibility of the opposite finding, of lower satisfaction in both respects for the Michigan women in general and for mothers in particular. The Michigan women, like the Stanford women, were an especially privileged group, but we surveyed the Michigan women five years out of law school, at a point when they were likely to have been at a particularly stressful stage in their careers and at particularly demanding stages in the lives of their young children.

On the following pages, I present information about the work and family situations of the Michigan women and men and the ways women and men accommodate work and family. I report the data that permit us to test the competing hypotheses about the satisfactions of the women and men lawyers, with and without children, with the balance of their family and professional lives and with their careers overall. More will be said about women's experience than about men's because both women and men perceived women as giving more attention to the family and making more deliberate adjustments.

42. Id. at 1245 .

43. Id. at 1245-46. The study did not compare the job satisfaction of women with and women without children. 


\section{THE UNIVERSITY OF MICHIGAN ALUMNI SURVEY}

The findings reported here were gathered in three studies of the graduates of the classes of 1976-79 at the University of Michigan Law School, the first four classes in which more than $20 \%$ of the graduates were women. The classes were first surveyed, by mail, one class each year, between 1981 and 1984 at the point when the graduates had been out of law school 5 years, part of an ongoing survey by Michigan Law School of its graduates 5 and 15 years after they finished law school.44 The 12-page mailed questionnaire inquired about the graduates' jobs and families and solicited views about the school.

The alumni surveys have not been designed to focus on differences in the experiences of women and men. Accordingly, in 1984 and 1986, further questionnaires were sent out that included questions tailored to explore gender differences. The 1984 survey, which was mailed to all women who had responded to the original five-year survey and to a roughly equal, randomly selected number of the men who had responded to the survey, relied largely on open-ended questions with space enough for responses of several sentences. It asked women about their perceptions of the effects of gender on their experiences during and after law school. It asked men the same sorts of questions, as well as questions about their perceptions of the experiences of the women attorneys with whom they worked. The final questionnaire, much shorter, was mailed in 1986 to all those who had responded to the original survey and served primarily to chart the changes in numbers of children, work settings, job status, and career satisfaction that had occurred since the five-year survey.

Response rates to the surveys have been consistently high. Of the 1,502 graduates in the four classes we studied, 1,070 responded to the fiveyear survey- $68 \%$ of the women (239 respondents) and $72 \%$ of the men (831 respondents). The great majority of those who responded to the first survey also responded to the later two. ${ }^{45}$

In addition to the surveys, we also coded a few items of information from the files of all members of these classes-particularly information from their original applications to law school and information about law school grades. From this information, we were able to explore, to a limited extent, whether there were significant differences between respondents

44. The Law School has surveyed $1968-83$ graduates 5 years after graduation and 1952-73 graduates 15 years after graduation.

45. The second and third questionnaires were sent only to those who responded to the first questionnaire; $82 \%$ of these women responded to the second questionnaire and $86 \%$ of them responded to the third. Of the men to whom the second questionnaire was sent, $77 \%$ responded, and of those responding to the first questionnaite $86 \%$ responded to the third. In all, $63 \%$ of the women and $62 \%$ of the men in the four classes responded to the original questionnaire and at least one of the two others. 
and nonrespondents. Lamentably for our purposes, persons with low grades as law students, roughly those in the bottom sixth of the class, were underrepresented among the respondents. ${ }^{46}$ Because of the relationship we found elsewhere in our analysis between grades and job opportunities, we suspect that this group includes a disproportionate number of the persons, male and female, who were not satisfied with their careers. ${ }^{47}$

\section{THE WORK SETTINGS AND FAMILY STRUCTURES OF THE MICHIGAN LAWYERS}

\section{A. Work Settings}

The Michigan graduates work more often in private practice than in any other sort of setting, but far more of the Michigan women than the men worked in settings other than private practice. As table 1 displays, five years after graduation, $70 \%$ of men but only $44 \%$ of women worked in private firms (or solo practice). Women were substantially more likely than men to be practicing law in corporate general counsel's offices or in government and to be working in such settings as teaching or government agencies where they did not regard themselves to be practicing law at all.48 Studies by others have also found that other women attorneys in the United States work more often than men in settings other than private practice, but the difference between the Michigan women and men is greater than that reported in such studies. ${ }^{49}$

46. Of persons with final grade-point averages in roughly the bottom sixth of the class, only $42 \%$ of the women and $58 \%$ of the men responded, in contrast with $75 \%$ of women and $76 \%$ of men in the upper five-sixths of the class.

47. Another underrepresentation is also possible for which we cannot test. One group that might respond less often than others are those who feel so beleaguered by their work and other responsibilities that they do not have time to respond. This group might include a disproportionate number of the full-time working women with children. If such underreporting did occur, it might affect the validity of our central conclusions about the career satisfactions of women with children. A substantial underreporting by this group of mothers seems unlikely because the response rate for women is about the same as the response rate for men and because the number of women with children within our sample closely parallels census information on fertility for professional women.

48. By the same token, women were also substantially more likely than men never to have worked in private practice. (Five years out of law school, $17 \%$ of men and $33 \%$ of women had never worked in private practice.) And among women and men who had ever worked in private practice, women were substantially more likely to have left private practice to work in other settings. (Five years out of law school, $17 \%$ of men and $34 \%$ of women who had ever worked in private practice had left to work in other settings.)

49. B. Curran et al., Supplement to the Lauyer Statistical Report: The U.S. Legal Profession in 1985 at 3 (1986) ("Curran, Supplement") (in 1985, of lawyers in the United States 39 or younger, $63 \%$ of women and $76 \%$ of men worked in private practice; $17 \%$ of women and $8 \%$ of men worked in government, legal services, or as public defenders); L. Vogt, From Law School to Career: Where Do Graduates Go and What Do They Do? 89-94 (1986) (reporting a complex mix: women in the class of 1974 at seven schools 11 years after graduation were less often than men in firms and more often in government, but in the class of 1981 sur- 
TABLE 1

Major Settings of Work for Women and Men Five Years After Graduation, University of Michigan Law School Classes of 1976-79

\begin{tabular}{|c|c|c|c|c|}
\hline \multirow[b]{2}{*}{ Work Setting } & \multicolumn{2}{|c|}{ Women } & \multicolumn{2}{|c|}{ Men } \\
\hline & $\mathbf{N}$ & $\%$ & $\mathbf{N}$ & $\%$ \\
\hline Solo or firm practice & 106 & 44 & 578 & 70 \\
\hline $\begin{array}{l}\text { Practicing in setting other than private } \\
\text { practice }\end{array}$ & 89 & 37 & 174 & 21 \\
\hline $\begin{array}{l}\text { Employed in work other than practice of } \\
\text { law (e.g., teaching, business) }\end{array}$ & 35 & 15 & 76 & 9 \\
\hline Full-time parent & 9 & 4 & - & 一 \\
\hline Total & 239 & 100 & 828 & 100 \\
\hline
\end{tabular}

For all their differences, the Michigan women's and men's work settings were, in some respects, more like each other than they were like the work settings of comparably aged lawyers elsewhere. Both for this age group nationally and for the Michigan graduates, private practice is the most common work setting. Michigan graduates, however, are far more likely than other lawyers to be in large firms and far less likely to be working as sole practitioners..$^{50}$ Of those who work in government, nationally most attorneys work in state or local government, whereas most Michigan graduates worked for the federal government. ${ }^{51}$

\section{B. Patterns of Marriage, Nonmarital Partners, and Children}

At the time they graduated from law school, roughly a third of both the Michigan women and men in the classes of 1976-79 were married. Over the five years that followed, roughly half the unmarried group mar-

veyed 4 years after graduation far smaller differences were found between women and men). For figures in other nations, see C. Menkel-Meadow, "Feminization" at 211-14 (cited in note 31 ).

50. Only $4 \%$ of the Michigan women and $6 \%$ of the Michigan men in private practice worked in solo practice, in comparison to $45 \%$ of women and $41 \%$ of men in private practice under 40 as reported in the census of lawyers prepared by the American Bar Foundation. Similarly, $51 \%$ of the Michigan women and $39 \%$ of the Michigan men in private practice worked in firms with more than 50 lawyers, in comparison to $19 \%$ of the women and $14 \%$ of the men under 40 in the national survey. See Curran, Supplement 4.

51. Among lawyers under 40 in the national survey (id.), $33 \%$ worked for the federal government. Among the Michigan graduates working in government, $55 \%$ worked for the federal government. 
ried for the first time.52 A few of the women and men lived with a nonmarital partner. In all, by the time of the five-year survey, about three quarters of both the women and men were married or had a partner. ${ }^{53}$

Although roughly the same numbers of men and women had pariners, the partners of the men and women differed dramatically in their occupations. Not surprisingly, many men but only one woman were married to homemakers. ${ }^{54}$ Conversely, many more women than men had partners who were lawyers- $45 \%$ of women with partners, $9 \%$ of men with partners. In fact, three of every five women who had married since law school married lawyers. ${ }^{55}$ The substantial majority of women whose partners were not lawyers had partners who were other professionals, business owners, or managers.

As the occupations of their partners suggest, the women with partners in our sample were typically linked with someone who earned about as much as they did or earned more than they did. That was true for $80 \%$ of the women. ${ }^{56}$ By contrast, the great majority of men with partners$89 \%$-were linked to someone who earned much less than they did or did not have a job in the labor force at all. ${ }^{57}$

At the time of the five-year surveys, when the median age of the women in our sample was 31 , only $37 \%$ of the Michigan women had any children, and only $11 \%$ had two or more children, a far lower number than is found among women in general in the American population..$^{58}$ At

52. Slightly fewer of the Michigan women and men were married than is the case among the American population in general. In 1980, in roughly the same age group as the Michigan group in the nation as a whole (persons aged $30-34$ ), $77 \%$ of women and $76 \%$ of men were currently married. Bureau of the Census, 2 Subject Reports $4 c$, table 1, 1980 Census of the Population, Marital Characteristics. At the time of the five-year survey, $63 \%$ of the Michigan women and $68 \%$ of the Michigan men were married.

53. Somewhat more of the women than men within the Michigan sample had been divorced at some point in their lives- $18 \%$ of women, $9 \%$ of men. On the other hand, among those who had been divorced, somewhat more of the women than men had been remarried or had a new partner by the time of the five-year survey.

54. In $1984,23 \%$ of men with spouses or partners had partners who were homemakers. Some of the men who reported that their partner was a homemaker may have had a partner who was trained as an attorney.

55. Fifty-nine percent of women marrying since law school (as compared to $29 \%$ of those marrying before the end of law school) were married to lawyers.

56. In fact, only 2 of 160 men with partners responding to the 1984 survey said that they were married to a woman who earned more than they did.

57. Even the men who were married to professionals or managers were typically married to lesser earning professionals or managers than those to whom the women were married. As a consequence of the differences in partner occupations and status, total family income for women with partners was substantially higher than the family income for men with partners. Five years after law school, $61 \%$ of women with partners but only $25 \%$ of men with partners had joint incomes greater than $\$ 75,000$. Indeed, a third of women with partners but only $6 \%$ of men with partners had joint incomes of more than $\$ 100,000$.

58. At the time of the 1980 national census, $80 \%$ of American women between 30 and 34 had given birth to at least one child and $60 \%$ had had at least two. The data for the Michigan women are consistent with national census information that women in professional occupations such as law or medicine have lower birth rates than women in any other 
that point, slightly more of the men- $41 \%$-had at least one child. Between the time of the five-year surveys (conducted in 1981 through 1984) and the final survey in 1986 , many women and men had a first child. ${ }^{59}$ Nonetheless, as of $1986,44 \%$ of the women and $39 \%$ of the men remained childless. The difference between women and men, though minor, may seem more substantial when the women's and men's remaining childbearing years are considered, for by 1986 the great majority of the women in the sample were in their mid- or late thirties.

Merging the information about children with the information about partners, we find, as displayed in table 2, that five years after law school

\section{TABLE 2}

Marital and Parental Status, Women and Men, Five Years After Graduation, University of Michigan Law School Classes of 1976-79

\begin{tabular}{lrrrrr}
\hline & \multicolumn{2}{c}{ Women } & \multicolumn{2}{c}{ Men } \\
& N & \% & & N & \% \\
\hline Unmarried, no children & 60 & 25 & 218 & 26 \\
Married or partner, no children & 91 & 38 & 276 & 33 \\
Married, with children & 83 & 35 & 321 & 39 \\
$\begin{array}{l}\text { Divored with children } \\
\quad \text { Total }\end{array}$ & $\frac{5}{239}$ & $\frac{2}{100}$ & & $\frac{16}{831}$ & $\frac{2}{100}$ \\
\hline
\end{tabular}

there were three substantial groups: married persons with children, married or partnered persons without children, and single persons without children. What there were very few of (at five years and in 1986) were women or men who had children but were currently single or divorced. At the time of the five-year survey, only 5 of the 88 women with children were divorced and had not remarried.

In the five-year survey, we asked all respondents to rate on a sevenpoint scale how satisfied they were with their family lives. Few of either sex in any marital status placed themselves in the lowest categories, but, on the whole, married and cohabiting people were much more satisfied than single people. Of those with partners $86 \%$ of women and $85 \%$ of men registered themselves as quite satisfied with their family lives (categories 1 and 2 on the 7-point scale), while of single, noncohabiting persons, only $35 \%$ of women and $37 \%$ of men so reported themselves. On the other

occupational group. Bureau of the Census, U.S. Summary, vol. 1, Characteristics of the Population, Detailed Population Characteristics, part 1, ch. D, table 271.

59. The proportion who had had any children rose from $37 \%$ to $56 \%$ of the women and from $41 \%$ to $61 \%$ of the men. 
hand, among people with partners, there were no substantial differences for either women or men between the levels of satisfaction with family of those with and those without children. It was having a partner, not having children, that corresponded with family-life satisfaction. ${ }^{60}$

\section{MANAGING THE DEMANDS OF FAMILY AND WORK}

\section{A. How Women Perceive the Demands}

The great majority of the women in our survey believed that they gave more time than men to family. On the 1984 survey, we asked women: "Do you believe that, for reasons that relate to your being a woman, you balance your career and private life differently than most men you know doing comparable work?" If they answered yes, we asked them to explain how. Three-quarters of all responding women said they did balance their private and professional lives differently from most men doing comparable work and, of this group, only three women said they gave less time than men to their private lives. Almost all the rest said that they gave more effort than men in comparable work to their private or family lives. ${ }^{61}$

No other open-ended question produced such a large number of similar answers. Many women who saw few other differences between their experiences and the experiences of men seemed to assume that they, and other women, would devote more effort than men to their family and private lives. ${ }^{62}$

The tones of women's responses vary. Many speak of their compara-

60. The differences in the reported satisfactions of married and unmarried people may be distorted by the form of the question we asked. Respondents were asked about their satisfaction with their "family" lives, not their "private" lives or their lives "apart from their careers." Thus our question may fail to capture, especially for unmarried people, their satisfaction with their social lives apart from interactions with persons who would be considered "family." Nonetheless our findings do parallel the findings of others who have found single persons less contented with their "family" lives and their lives on the whole than married persons and also that marital status is more significant than children in accounting for satisfaction with family life. Campbell, Converse, Rogers, Quality 336-40 (cited in note 4).

61. We did not ask men a comparable question about the balance of their private and professional lives, but about a third of men gave family reasons as an explanation for the lower incidence of women in private practice, suggesting that many men also believe that female attorneys pay more attention to family matters than male attorneys. See infra at 268-69.

62. In a study of the 1976,1977 , and 1978 graduates of Berkeley, Columbia, and Pennsylvania Law Schools, Linda Lefland found that most women with children (65\%) reported spending more time with their children than their husbands or former husbands did and that even more of the men (84\%) reported spending less time with their children than their wives or former wives. "Career Patterns of Male and Female Lawyers," 35 Buffalo $L$ Rev. $601,607-8$ (1986). 
tively higher involvement with children and family with pleasure, pride, or a touch of defiance:

My family life is more important to me. (I would not have said this before I had children.) . . . I love my work but will not be an absentee parent. My husband (also an attorney) would not say this.

Absolutely. ... I've tried the "total immersion" approach and find I cannot stay sane for very long. I must have another activity separate from "the law" where I can clear my mind of all the debris and frustrations of my job.

I know there is life outside the law firm (apart from children, which I don't have). Many men appear to be relatively blind to this (but not all).

Now after my first child, no matter how much my husband and I attempt to "share" the responsibility, I find that by my own choice, I have primary responsibility for our child and my child is a higher priority than my work. lawyer.

I decided my parents and children came first. Anyone can be a

Other women seem to experience their position less as one assumed by choice than by assignment. They speak of the balance of work and family with resignation or frustration:

I am a mother with two small children and expecting a third. No further explanation is necessary.

I spend far more time with my children [than most men in comparable work]. I go home three days a week to take my child home from school. I take him to school three days a week. I get the groceries and the babysitters. I take them to the doctors, etc., even though my husband and I are . . . both partners in the same law firm.

I "balance" by losing myself-my free time. I have no hobbies, little time to assess who I am and where I want to go. I "balance" by forgoing social opportunities and chit-chat with peers.

I value my marriage and my friends. I have a two-year-old and am expecting another. I am half crazy because I put in fewer hours at work than my colleagues and I feel I am falling behind.

Not surprisingly, the women who were parents were more likely than other women to say that they gave more time to family matters. Table 3 
indicates that, when surveyed in $1984,15 \%$ of mothers were not working in the labor force at all, and an additional $13 \%$ worked part time only.

\section{TABLE 3}

How Women Balance Their Private and Professional Lives in Comparison to Men in Similar Occupations, as Reported by Women With and Without Children, 1984 Survey, University of Michigan Law School Classes of 1976-79

\begin{tabular}{|c|c|c|c|c|c|c|}
\hline & \multicolumn{3}{|c|}{$\begin{array}{l}\text { Women Without } \\
\text { Children }\end{array}$} & \multicolumn{3}{|c|}{$\begin{array}{l}\text { Women With } \\
\text { Children }\end{array}$} \\
\hline & $\mathbf{N}$ & $\%$ & & $\mathbf{N}$ & $\%$ & \\
\hline $\begin{array}{l}\text { Women serving as full-time } \\
\text { homemaker or childtender }\end{array}$ & 0 & 0 & & 12 & 15 & \\
\hline $\begin{array}{l}\text { Women working part time for } \\
\text { family reasons }\end{array}$ & 2 & 2 & & 10 & 13 & \\
\hline $\begin{array}{l}\text { Full-rime working women } \\
\text { reporting that they: }\end{array}$ & & & $45 \%$ & & & $90 \%$ \\
\hline $\begin{array}{l}\text { Give more time to family/ } \\
\text { private life than men in } \\
\text { comparable work }\end{array}$ & 37 & 43 & & 48 & 62 & \\
\hline $\begin{array}{l}\text { Give no more time but regret } \\
\text { having no "wife" at home }\end{array}$ & 4 & 5 & & 0 & 0 & \\
\hline $\begin{array}{l}\text { Balance private/family life } \\
\text { same as men in comparable } \\
\text { work }\end{array}$ & 38 & 44 & & 6 & 8 & \\
\hline $\begin{array}{l}\text { Give less time to family than } \\
\text { most men in comparable } \\
\text { work (to prove self) }\end{array}$ & 2 & 2 & & 0 & 0 & \\
\hline Other & 4 & 5 & & 2 & 3 & \\
\hline Missing data & (8) & - & & (2) & - & \\
\hline Total & 87 & 100 & & 78 & 100 & \\
\hline
\end{tabular}

And among the full-time working mothers, 48 of 56 asserted they gave more effort to family than most men in comparable work. In all, $90 \%$ of mothers either did not work outside the home, worked part time, or worked full time but believed they gave more effort to family than men in comparable work. Women with children are not, however, the only women who believe that they give more attention to family than men. Two married women without children worked part time for family reasons, and nearly half of the remaining women without children said they also gave 
more effort to family or private lives than the men they knew in comparable work.

As the excerpts convey, the women's attitudes ranged from regarding their private lives as their salvation to regarding themselves in constant crisis in coping with the conflicting demands of their private and professional lives. Indeed, a quarter of women with children, in response to another open-ended question, identified the conflicting demands of family and work as "the most important way that being a woman has disadvantaged (them) in (their) career since law school."63 A smaller number of married women without children (about $12 \%$ ) gave the same response. ${ }^{64}$

\section{B. How Women and Men Accommodate Work and Family}

How did women and men accommodate their professional and family lives and how did women do so differently than men?

A principal way to seek a more reasonable balance of family and work is to reduce the amount of time spent at work.65 Many women, but few men, have made such adjustments. As already noted (see table 2), at the time of the 1984 questionnaire, $28 \%$ of women with children were working part time or had ceased working outside the home. In 1986, when the classes we surveyed had been out of law school seven to ten years, nearly $70 \%$ of the women with children reported that, at some point since law school, they had, for three or more months, worked part time or stopped working outside the home altogether. A quarter of the women with children had taken much longer periods-at least 18 months-of either fulltime parenting or part-time work. Very few men had ever taken leaves of absence or worked part time to care for children, although a few men said they were constrained by the roles expected of men from asking their employers for leaves that women were freely granted. One male associate in a private firm wrote, "I find it extremely frustrating . . . when I encounter the 'good old boy' attitude that I am 'out of line' or 'weak' when I express or demonstrate by action that my wife and daughter are by far my top priority. While it is accepted that females may take extended leaves to start a family, it is not accepted that males may do so."

The great majority of women and nearly all men worked full time.

63. Conversely, $6 \%$ of men, asked the greatest advantage to them of being a male, pointed to their being free of the special family responsibilities women assume.

64. One married woman without children complained, for example, of the resentment her husband felt toward her high earnings, another of having to move twice to accommodate her husband's employment.

65. For a study of law firms' responses to lawyers' (and particularly women lawyers') family-related needs, see Note, "Law Firms and Lawyers with Children: An Empirical Analysis of Family/Work Conflicts," 34 Stan. L. Rev. 1163 (1982). 
Among those with full-time jobs, women with children worked only slightly fewer hours than others. Women with children report working, on average, about three fewer hours than other women and four fewer hours than men, a difference that was statistically significant. The principal striking fact within our data is, however, not that women with children worked slightly fewer hours but how long the work weeks were for almost everyone who considered themselves to be working "full time."66 For the classes of 1980 and 1981, for which we had the most complete and reliable information about hours worked, the full-time working mothers reported averaging 49 hours of work per week, 49 weeks a year, while other women and men averaged about 52 hours per week. Those are long work weeks. As a group, the only accommodation that full-time working women with children made in their work hours was that slightly fewer of them worked extremely long hours and slightly more of them worked somewhat shorter hours than other women or men. ${ }^{67}$ Men with children worked no fewer hours than men without children. Both worked brutal weeks.

A second way that women and men might have sought to achieve a sensible balance of work and family was through their choice of work settings. ${ }^{68}$ As we have seen in the preceding section, five years after law school and again in $1984,70 \%$ of men in these classes but only $44 \%$ of women worked in private practice. When, in one of our follow-up questionnaires, we asked the respondents whether they had any explanation for this difference in work settings, ${ }^{69}$ the most common explanation offered by women and the second most common offered by men was that women avoided private practice because they wanted settings where they could achieve an acceptable balance between work and their family or private lives. ${ }^{70}$ Many individual women described leaving a firm for familyrelated reasons. Many men reported with some remorse that men tolerate

66. For the 1976-79 classes, we classified persons who reported working more than 1,500 hours per year as working full time. For the 1980-81 classes, we asked people both the numbers of hours they worked and whether they considered themselves to be working part rime or full time. The mean number of hours worked by those who considered themselves part-time workers was about 1,500. A few people who said they worked full time worked less than 1,500 hours.

67. Of women with children, $13 \%$ report working 56 or more hours per week in comparison with $29 \%$ of women without children, $27 \%$ of men without children, and $28 \%$ of men with children. Conversely, $35 \%$ of the full-time working women with children but only $19 \%$ of the women without children averaged fewer than 45 hours of work per week.

68. See Note, "Law Firms and Lawyers with Children: An Empirical Analysis of Family/Work Conflicts," 34 Stan. L. Rev. 1263, 1289-92 (1982) (a survey of second- and thirdyear law students at Stanford finding that most women but few men said that policies regarding leaves and child care were a significant factor in their choice of employer).

69. Asked in open-ended form, without suggested responses, in the 1984 questionnaire.

70. The most common explanation offered by men was (and the second most common offered by women) that women were discriminated against or felt unwelcome or uncomfortable in the private firms. 
conditions that women refuse to accept. As one male expressed it, "Law firms consume $200 \%$ of one's time. There is no stability of hours and it is difficult to have a family life, or any other life." The perception that private practice interferes with family life is supported by our consistent finding that those who work in private practice-and especially those who work in large firms-are less satisfied with the balance of their family and professional lives than persons working in other settings. ${ }^{71}$

In the end, however, we cannot be certain whether many women have in fact rejected private practice for family-based reasons. We find wholly plausible the suggestion of the respondents that they have. On the other hand, we had expected to find that, among women, those with children would be especially likely to avoid private practice, and do not find that they do. Women with children were as likely as women without children to work in private practice. We had also believed that women who did work in private practice might tend to avoid the large firms where, as we have just reported, the stresses on family life are said to be most severe, but in fact, among those in private practice, a higher proportion of women than men worked in the large firms. ${ }^{72}$

All that this pattern suggests is that many factors contribute to women's decisions whether to work in private practice or in large-firm practice of which family considerations are only one. ${ }^{73}$ Many Michigan women have found jobs within private practice where they find support for their parenting responsibilities. Over half the women working part time at the time of the five-year survey worked in firms. A few women reported that the greatest advantage they had experienced in their careers was that a firm had accommodated their parental responsibilities in ways it might not have for a man. ${ }^{74}$

By the same token, we cannot know how much men were affected in their decisions to work in private practice or in settings where earnings are higher because they believed that they would be the principal earner within a family. One male in private practice observed, with regret, "I am the breadwinner in my family and feel that I must maintain a position that will provide a relatively affluent lifestyle. Therefore, I think that many potentially rewarding career options were closed to me."

71. At the time of the five-year survey, $55 \%$ of persons working in settings other than private practice were quite satisfied (categories 1 or 2 of 7 ) with the balance of their family and private lives, in contrast to $40 \%$ of those in private firms with 50 or fewer lawyers and $28 \%$ of those in private firms with more than 50 lawyers. Essentially the same differences were found for the same classes in 1986 and for the classes of 1980 and 1981 at the time of their five-year surveys.

72. Fewer women than men worked in private practice, but, among those in private practice, $51 \%$ of women and $39 \%$ of men worked in firms of more than 50 lawyers.

73. Discrimination by other attorneys and clients may, for example, be an even greater problem for women in small and mid-sized firms than it is for women in large firms.

74. "I think my firm is more willing to accommodate a woman's personal goals (i.e., motherhood) than a man's by allowing part-time work, reduced hours, etc." 
There is some mild evidence within our data that other men were also affected in their job choices by such considerations. Five years after law school, men who were married earned somewhat more and were somewhat more likely to be working in private practice than men who were single, suggesting deliberate choices by "family" men to work in high-paying settings. ${ }^{75}$ In addition, among men who began law school planning to work in legal services for the poor or "public interest" work (where earnings are lower than in firms), men who had married by the end of law school were less likely to carry through on their plans than men who were still single. ${ }^{76}$

A final way that women and men might have accommodated their family and professional lives was by spending less time on "nonessential" activities apart from family. One of the women we quoted above spoke of having no hobbies and of "forgoing social opportunities and chit-chat with peers." Others spoke of forgoing exercise and sports that men engaged in. We have no statistical information about hobbies or sports. We did ask about participation in electoral and nonelectoral political activities and in bar associations or other lawyers' organizations, and in these activities no differences appeared between full-time working women and men or between women or men who were parents and those who were not. ${ }^{77}$ The only activities in which differences appeared were in time spent socializing with clients or co-workers. Few men or women, with or without children, reported spending much time doing so, but women with children reported spending somewhat less time than other women or than men. ${ }^{78}$

75. Married men averaged earnings of $\$ 48,900$, unmarried men averaged $\$ 45,300$. $P .<02$. Similarly, $74 \%$ of married men and $61 \%$ of unmarried men were in private practice. On the other hand, there was no difference between the earnings of married and unmarried women, nor was there any difference in the proportions of married and unmarried women who were in private practice.

76. Of the members of the 1976-79 classes, $12 \%$ remember beginning law school with a plan to work for legal services for the poor, as a public defender, or in a "public interest" group. As a group these jobs pay far less than other categories of jobs available to the Michigan lawyers. We looked to see whether persons who were married at the end of law school were as likely to stick to their plans as persons who were not. We hypothesized that men who had married by the end of law school (and about a third had) would be less likely than unmarried men to adhere to their plans to work in these settings, but that women who were married (and who might feel in the position of a "second" earner) would be more likely than unmarried women to adhere to their plans. For men only, the predicted pattern held true. Of those who had planned to work in legal services or similar work, a third of the unmarried men, but only $7 \%$ of the married men actually did. Of course, it is possible that men first gave up their plans and later decided to marry bur, either way, there appears, for many men, some relationship between job choices and marriage. For women, there is no significant difference between the married and unmarried women.

77. Whether parents or not, about $30 \%$ of men and women said they were active in electoral or nonelectoral politics. Similarly, about a third of all women and men said they were active in a bar association or other lawyer's professional group (such as the National Lawyers Guild or a trial lawyers association).

78. On average, women with children reported spending $2.0 \%$ of work time socializing with clients or co-workers; women without children, $3.2 \%$; men with children, $3.8 \%$; and men without children, $3.7 \%$. We are doubtful about the accuracy of people's recollections about the amount of time they spend socializing with colleagues and co-workers. A great 


\section{The Satisfactions of Women and Men with the Balance of Work and Family}

How successful were women's and men's efforts to balance their family and professional lives?

Respondents to the five-year survey were asked to respond on a sevenpoint scale to a question asking "how satisfied are you" with the balance you have "struck between your family life and your professional life." Their responses indicated that, for both men and women, conflicts between their family and professional lives caused problems. Most people were markedly less satisfied with the balance of their family and professional lives than they were, for example, with their family lives considered alone or with their incomes, their prestige in the community, or their careers overall. Table 4 displays what we found with regard to satisfaction with the balance, comparing the satisfactions of women and men, with and without partners and children. The responses were somewhat surprising.

In general, as is revealed by the totals in table 4 , women were slightly more contented than men with the balance of their family and professional lives. Moreover, women with children were somewhat more contented with the balance than single women and than married women without children and much more contented than men with children and men who were single. ${ }^{79}$ In comparison with all other groups, far fewer of the women with children were dissatisfied with the balance. ${ }^{80}$ Single persons of both sexes are less satisfied than persons with spouses or partners. The differences between men and women and between women with children and others remain after regression analysis taking into account other factors that bear on satisfaction with the balance of career and family. ${ }^{81}$ When we resurveyed the same classes in 1986 , seven to ten years after graduation, a slightly different pattern emerged. At this point, no significant differences appeared among the groups. Women with children were as satisfied, but no more satisfied, with the balance than were other women and than men

many people said they spend $0 \%$ of their time socializing, and we suspect that very few people are so pressured or misanthropic that they never chat with co-workers. On the other hand, even if there is underreporting in general, the gender differences still appear noteworthy.

79. In each pair of comparisons, women with children were statistically significantly more satisfied.

80. Among men, men with partners but no children were somewhat more satisfied with the balance than men without partners or than men with children.

81. For both men and women, the strongest factor in accounting for satisfaction with the balance is whether the person worked in private practice. Persons in private practice were less satisfied with the balance. But even after taking private practice into account, gender and parenting status remain significant. The five-year survey of the classes of 1980 and 1981 elicited more hours worked and the fact of working in private practice were negatively related to satisfaction with the balance. For women and men in these classes, having a spouse or partner was more strongly related to satisfaction with the balance than was having children. 
TABLE 4

Satisfaction with Balance of Their Family and Professional Lives, Full-Time Working Men and Women Five Years After Graduation, University of Michigan Law School Classes of 1976-79

\begin{tabular}{|c|c|c|c|c|}
\hline & $N$ & $\begin{array}{l}\text { \% Quite } \\
\text { Satisfied }^{2} \\
\end{array}$ & $\begin{array}{c}\text { \% Dis- } \\
\text { satisfied }^{b}\end{array}$ & Mean \\
\hline & \multicolumn{4}{|c|}{ Women } \\
\hline \multicolumn{5}{|c|}{ Women who were: } \\
\hline $\begin{array}{l}\text { Single, no } \\
\text { children }\end{array}$ & 55 & 42 & 26 & 3.27 \\
\hline $\begin{array}{l}\text { Married or } \\
\text { partner, no } \\
\text { children }\end{array}$ & 86 & 40 & 21 & 3.04 \\
\hline Parents & 66 & 56 & 9 & 2.56 \\
\hline \multirow[t]{3}{*}{ All cases } & 207 & 45 & 18 & 2.95 \\
\hline & & & & $p<.02$ \\
\hline & \multicolumn{4}{|c|}{ Men } \\
\hline
\end{tabular}

Men who were:
Single, no children
Married or partner, no children

Parents All cases
202 265

319

786
32

34

3.24

39

20

24

3.26

* Registering themselves 1 or 2 on 7-point scale.

b Registering themselves 5,6 , or 7 on 7-point scale.

with and without children. ${ }^{82}$

We will reflect more on the significance of these findings after reporting in the next section on overall career satisfaction. At this point a word of caution should nonetheless be repeated. Remember that both men and women, including women with children, are, as groups, less contented with

82. In 1986, the mean of the women with children was 2.86; of women without children, 3.08; of men with children, 2.94; of men without children, 2.98. The lower the number, the higher the satisfaction. Differences not significant. 
the balance of family and work than they are with almost all other aspects of their careers about which we inquired. Balancing family and professional life is stressful even if women with children appear comparatively successful at the task.

\section{CAREER SATISFACTION OF WOMEN AND MEN, MOTHERS AND FATHERS}

Most social scientists who study satisfaction with work ask people about their satisfaction with their "current job." We did not do so. We asked our respondents instead about their satisfaction with various aspects of their career since law school as a whole and with their careers overall. Respondents' experiences in their current jobs probably dominated their answers to these questions, but our question invited reflection on their entire professional experience since law school.

Most of the respondents were satisfied with their careers overall. As table 5 displays, about half of all women and men placed themselves in categories 1 or 2 out of 7, the groups we combine and label "quite satisfied." Most other persons put themselves into categories 3 or 4 , very few into categories 5,6 , or 7 . Given the stresses of the early years of practice, it may seem surprising that so many of the women and men expressed high satisfaction with their careers and that so few expressed low satisfaction. In fact, surveys of American workers report high job satisfactions for men and women workers across almost all sorts of employment. ${ }^{83}$

While the Michigan women and men do not differ significantly in their overall career satisfactions, differences do appear when their marital and parenting statuses are taken into account. As table 6 illustrates, single persons of both sexes are again less satisfied than those who are married or have partners. In addition, women who have children are significantly more satisfied with their careers than are married or single women without children. ${ }^{84}$ They are also significantly more satisfied than men with and without children. ${ }^{85}$ Women with children, a group that some might ex-

83. See Campbell, Converse \& Rodgers, Quality 63 (cited in note 4). Asked about their overall job satisfaction on a seven-point scale much like ours, $66 \%$ of workers in a large representative sample of Americans put themselves into the two most satisfied categories and only $4 \%$ put themselves into the two least satisfied categories. They found no differences in job satisfaction between women and men. Compare tables at 428 and 432.

84. Table 6 does not reveal the significance levels of pairs of comparisons. In pairs of analyses of variance, women with children are significantly more satisfied with their careers overall than both childless women without partners $(p<.005)$ and childless women with partners $(p<.04)$.

85. Table 6 does not reveal the significance levels of pairs of comparisons. Women with children are significantly more satisfied with their careers than both men with children $(p<.005)$ and men without children $(p<.005)$. 


\section{TABLE 5}

\section{Overall Career Satisfaction of Full-Time Working Women and Men Five Years After Graduation, University of Michigan Law School Classes of 1976-79}

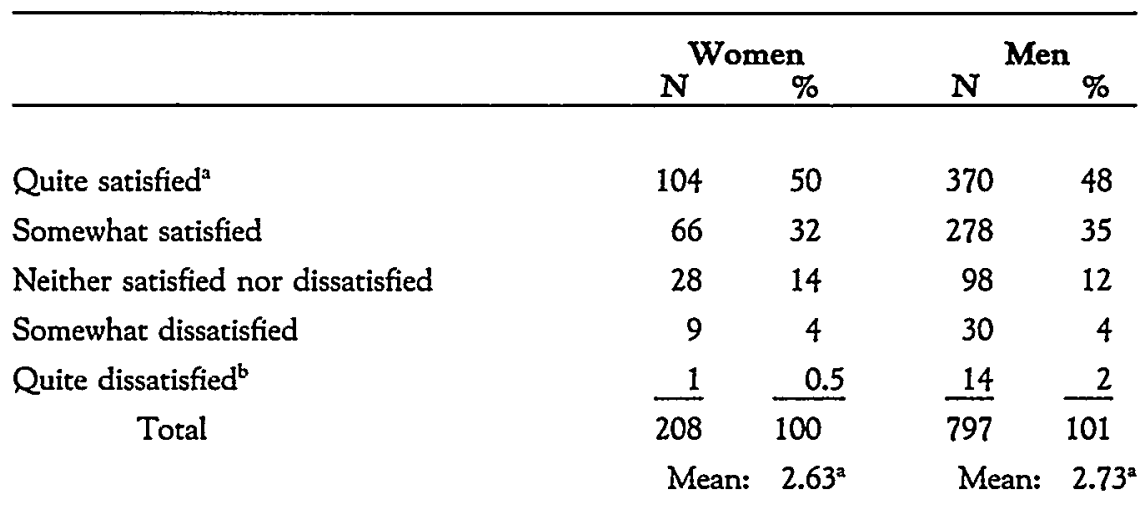

- The differences between the women and men were not statistically significant.

b The questions about satisfaction had seven categories. The most positive categories, 1 and 2, are grouped as "quite satisfied" and the least positive, 6 and 7, grouped as "quite dissatisfied."

pect to be unsatisfied absolutely and in comparison to other women and men, prove to be generally well satisfied-and more satisfied than others.

Because the apparent relationship between parenting status and career satisfaction might have been spurious, we examined widely within the available data for other factors that might better explain the differences in career satisfaction. We examined women and men separately and together. We looked at the relation between career satisfaction and individual income, family income, marital status, partnership or managerial status at work, type of work setting (private practice or other), political attitudes, law school grades, numbers of hours worked, and many other factors. ${ }^{86}$ None of them, including parenting status, explained all or even most of the differences among the respondents' career satisfaction. ${ }^{87}$ On the other hand, among women, but not among men, the fact of having children remained significantly related to career satisfaction after taking other fac-

86. Because of a lower response rate to the questionnaire by blacks and other persons of color, we did not include race in the variables used to try to explain difference in levels of satisfaction.

87. No item of information, that is, neatly divided the satisfied from the dissatisfied. As to parenting in particular, despite the fact that, on average, mothers were more happy than nonmothers, there were (as table 6 makes clear) many mothers who were not very satisfied with their careers and many nonmothers who were quite satisfied with theirs. The same was true for other variables that bore some relation to satisfaction. 
tors into account, and was in fact the third strongest factor we could identify. ${ }^{88}$

\section{TABLE 6}

Overall Career Satisfaction by Marital and Parental Status of FullTime Working Women and Men Five Years After Graduation, University of Michigan Law School Classes of 1976-79

\begin{tabular}{|c|c|c|c|c|}
\hline & $\mathbf{N}$ & $\begin{array}{l}\% \text { Quite } \\
\text { Satisfied }^{*}\end{array}$ & $\begin{array}{c}\text { \% Dis- } \\
\text { satisfied }^{\text {b }}\end{array}$ & Mean \\
\hline & \multicolumn{4}{|c|}{ Women } \\
\hline \multicolumn{5}{|l|}{ Women who were: } \\
\hline Single, no children & 56 & 38 & 9 & 2.95 \\
\hline $\begin{array}{l}\text { Married or partner, } \\
\text { no children }\end{array}$ & 86 & 48 & 6 & 2.65 \\
\hline Parents & 66 & 64 & 0 & 2.32 \\
\hline \multirow[t]{2}{*}{ All cases } & 208 & 50 & 5 & 2.63 \\
\hline & \multicolumn{4}{|c|}{ Men } \\
\hline
\end{tabular}

Men who were:

Single, no children

206

41

10

2.91

Married or partner, no children

263

49

321

49

Parents

790

47

18

All cases

\section{(19)}

' Registering themselves 1 or 2 on 7-point scale.

b Registering themselves 5,6 , or 7 on 7 -point scale.

88. In a regression on women's career satisfaction, five variables explained $17.2 \%$ of the variance (adjusted). The strongest of these was political attitude-the more liberal a woman regarded herself the less likely she was to be satisfied (7-point scale; $b=.25$, S.E. =.06). The second and third strongest, of nearly identical strength were final gradepoint average from law school (higher grade-point, higher satisfaction; grade point on 4-point scale; $b=.58$, S.E. $=.19$ ) and whether the woman had children (binary variable, $b=.47$, S.E. $=.14$ ). The other two significant variables, in declining order of significance, were whether the woman was currently in private practice (those in private practice less satisfied; a binary variable, $b=-.38$, S.E. $=.14$ ) and whether the woman had become a partner, supervisor, or manager (those who had were more satisfied; binary variable, $b=.41$, S.E. $=.17)$. 
Among men, both those with and without children, as the table above also reveals, men who had partners or wives were slightly more satisfied with their careers than men who were partnerless or single. The fact of having children, however, bore no measurable relationship to their career satisfaction. The difference in satisfaction between partnered and unpartnered men is statistically significant and retains significance after controlling for other available factors. ${ }^{89}$ The differences are nonetheless very slight.

The reported higher average satisfactions of the women with children at the five-year point were not transitory. When we surveyed the same women and men two to five years later in 1986, most graduates' reported level of satisfaction had changed very little. ${ }^{90}$ Women with children were still as a group more satisfied both with their careers as a whole and with the balance of their family and professional lives than women without children and than men with or without children.91 In fact, in 1986, for fulltime working women, having children correlated more strongly with career satisfaction than any other variable, even after taking the other variables into account. ${ }^{92}$ One pattern only was different in 1986: in the five-year survey, the women without children were somewhat less satisfied with their careers than the women with children but no less satisfied than the men; by 1986, women without children reported lower levels of career satisfaction than both women with children and men.

Our data permit us to compare not only the career satisfaction of women with and without children, but also the satisfaction of some women before and after they had children. Of the women who responded to our 1986 questionnaire, 130 had no children at the time of the five-year survey. Of this group, 36 had a first child after the five-year survey but before we resurveyed them in 1986 . Even with the burdens of a first child, half the new mothers reported higher career satisfaction in 1986 than they had reported at the time of the five-year survey (when their satisfaction

89. We can explain even less of the variance in the career satisfaction of men than we can of the satisfaction of women. The strongest factor we can identify is income (the higher the more satisfied), the next strongest is marital/partnered status, but the two combined explain only $3.7 \%$ of the variance and other variables add little to the explained variance.

90. Eighty percent of them reported a level of career satisfaction no more than one level away from the level they had reported at the time of the five-year survey.

91. In 1986, the mean career satisfaction level for women with children was 2.39 , while that for women without children was 2.99 , for men with children, 2.66, and men without children, 2.57. The number of individuals in the caregories of women with children and men with children grew between the two surveys because many men and women had had their first child between the five-year survey and 1986.

92. For the factor of having children, $b=-.64$, S.E. $=.17$. The other significantly related factors were, in order, law school grade point (higher grades, lower satisfaction, $b=.50$, S.E.=.24); whether she was a partner, manager, or supervisor at her current place of work (partners and managers more satisfied, $b=.33$, S.E. $=.19$ ); and whether she was currently in private practice (those in private practice less satisfied, $b=.28$, S.E. $=.18$ ). Taken together, these four variables explain $9 \%$ of the adjusted variance in career satisfaction. 
levels were already high), and only a quarter reported lower satisfaction. In contrast, the 94 women who remained childless after the five-year survey display the opposite pattern. More of them were less satisfied at the time of the 1986 survey than they had been at the time of the five-year survey. ${ }^{93}$ Thus, for women, having a child seems to have been associated with somewhat increased career satisfaction. ${ }^{94}$ For men, by contrast, having a first child (or not having children) bore no relation to changes in levels of career satisfaction between the two surveys.

For our purposes, the most important point about the women with children is probably not that they seem somewhat more satisfied than others but that, despite all the reasons why it might be otherwise, they are fully as satisfied as the others. The next section explores the reasons why the women with children report the high levels of satisfaction that they do.

\section{DISCUSSION: ACCOMMODATIONS AND SATISFACTIONS}

The initial hypothesis with which this article began-that the Michigan women would devote more effort to children and family than the Michigan men-has, not surprisingly, been confirmed. Many women without children and nearly all women with children report giving more effort to family than men in comparable work. Women with children and women without are also much more likely than men to work in settings other than private practice, and men and women ascribe as a principal reason for women's avoidance of private practice that women want to work in settings more compatible with (or accepting of) their obligations or desires for a family life.

The women with children have made the most visible accommodations to the demands of family, but they have not done so in a single way. Most have, for some period of time since law school, ceased working outside the home or shifted to part-time work. (A quarter of the mothers, in fact, have worked part time or have taken leaves for periods totaling at least 18 months.) On the other hand, many women with children have

93. At the time of the five-year survey, the childless women who later became mothers were already slightly (but not significantly) more satisfied with their careers than the women who did not become mothers by 1986 . By $1986,49 \%$ of the women who became mothers were at least one level more satisfied than they had reported themselves to be in the five-year survey; $26 \%$ were less satisfied. By comparison, only $32 \%$ of the women who remained childless were at least one level more satisfied, while $41 \%$ were less satisfied. Of the 36 new mothers, 8 were working part time in 1986 and 4 had ceased working outside the home at all. These 12 mothers who did not have full-time jobs reported career satisfactions that were almost identical to the satisfactions of the full-time working mothers.

94. It is possible that the women who had children after the five-year survey were those who already felt more secure in their careers than they had at the time of the five-year survey and thus that in some sense the satisfaction "caused" the children and not the reverse. 
either consistently worked full time or, having taken a brief leave, swiftly returned to full-time work. The full-time working women with children lead professional lives quite similar to those of other women and men. They do average fewer hours at work than others, but the differences are slight and the most striking fact is how long the hours are that full-time working women and men, with and without children, work. Within the range of our data, women with children also seem to engage in as many professional and service activities (bar associations, political efforts, and so forth) as others. The full-time working women with children do almost all that everyone else does plus the extra efforts of parenting.

Do men make any adjustments in their lives because of familial responsibilities? Almost none of the men have ever worked part time or taken leaves to care for children, and the men with children work as long hours as men without. Some men express regret or even resentment that men are discouraged by employers and by social norms from participating more in the lives of their children, but few have actively resisted. To the slight extent that men with families have adjusted their lives because of family, they seemed to have done so by choosing, in even greater numbers than men without spouses or partners, to work in private practice where earnings are higher than in other settings. Some men, that is, have adjusted, perhaps unconsciously, by striving to be especially good providers.

How have these patterns of family situations and adjustments affected men's and women's satisfactions with their careers and with the balance of their family and professional lives. At the outset of this article, we hypothesized that single women and single men might be somewhat less satisfied than others, but we were uncertain what we would find for women with children, the group whom we expected to bear the heaviest familial responsibilities. Earlier writings of others pointed in conflicting directions. ${ }^{95}$ On the one hand, some recent writing about workers in general suggested that satisfaction with achievement in multiple roles might lead the Michigan women with children to feel as satisfied as others both with the balance of work and family and with their careers overall—or that they would be even more satisfied. On the other hand, much of the writing about lawyers in particular suggested that women with children might feel comparatively beleaguered, oppressed, and unsatisfied. Our findings have been that women with children are beleaguered but that they are also well satisfied. As we have seen, they are well satisfied with their careers overall, significantly more satisfied than other women and than men, and they are generally satisfied with the balance of their work and family lives, again significantly more satisfied than other women and men.

Why do women with children express this higher level of satisfaction? Is satisfaction with multiple roles the correct explanation? Or are other 
factors at work? We examined some possible factors in the introduction. Here are our own efforts to explain the satisfactions in the special context of the professional world of lawyers in which these women lived.

Explaining the satisfactions of the Michigan women with children, especially their career satisfaction, should probably begin with trying to explain the satisfaction of the Michigan women in general. Why, that is, are these women in general as satisfied as men, when there are so many reasons why women with and without children might be less contented? The Michigan women, after all, entered a profession that was still fully controlled by men, men who, as a group, had a bleak record for their response to earlier women lawyers. The ABA survey of young women and men lawyers in private practice in fact found women associates frequently dissatisfied and more frequently dissatisfied than men in comparable positions. ${ }^{96}$ This essay has not been devoted to a general inquiry into women's and men's experiences as lawyers, and I will not undertake one here, except to offer two hypotheses for the similar satisfactions of the women and men.

One hypothesis is suggested by the literature on relative deprivation. ${ }^{97}$ We have already seen that the women in the classes of 1976 through 1979 worked much less frequently in private practice than men (see table 1). Many men and women in these classes believe that women are not in private practice at least in part because of discriminatory hiring practices of the firms or because of a perception by women that they would be unfavorably treated in these settings. ${ }^{98}$ Whatever their setting of work, virtually all women in these classes report having experienced some discrimination from other lawyers, judges, or clients during the time they have been in practice. In nearly all settings, women report a continual need to prove that they are "tough enough" and that they are committed to their careers. Thus, when women report themselves, as they do, to be as satisfied with their careers as men report themselves, it is tempting to explain it on the grounds that they have simply become inured to oppression or, at least, made peace with second best.

That explanation is plausible and probably does explain the expressions of satisfaction of some Michigan women, just as it explains the satisfaction of many women stuck in low-paying jobs socially identified as "women's work." Equally plausible, however, is that the Michigan women have a genuine foundation for satisfaction with their accomplishments, at least if satisfaction is measured by traditional criteria within the profession. Few seem to have experienced themselves as transforming lawyering into a distinctly woman's experience, but most appear to experience themselves

96. See p. 258 supra.

97. See Crosby, Deprivation (cited in note 25).

98. See supra note 70. 
as succeeding in the male-shaped world of law as they found it. ${ }^{99}$ They have proven themselves "tough enough." They have experienced discrimination at some points in hiring interviews or in encounters with lawyers with whom they worked, but they have rarely found that these experiences held them back from achievement. ${ }^{100}$ They earn as much as men in the settings in which they work. They report as frequently as men having mentors, usually male mentors, who have been especially helpful in their careers. They are as satisfied as men with the quality of their relationships with the persons with whom they work. They may work much more often than men in settings other than private practice, but few seem to regard these other settings as second best. ${ }^{101}$

When we then turn to trying to explain the especially high satisfaction of women with children, much the same sorts of competing explanations are possible - and are, as will be explained, similarly resistant to firm empirical proof.

A first explanation is that the women with young children may face enormous stress, yet report that they are quite satisfied with their careers because they have an especially strong need to believe that they are managing their lives successfully. They may, that is, be engaging in reaction formation or denial. ${ }^{102} \mathrm{Or}$, less patronizingly and somewhat more positively, these women with several areas of responsibility in their lives may develop more "realistic" expectations for each than men do. They accept a tension between private and professional life as inevitable and adjust their standards accordingly. One mother who reported herself quite satisfied with the balance of her family and professional life and with her career overall wrote, "I get so tired of being tired and doing my career and home both more half-assed than I am used to doing. It's hard to stop doing one's very best, but I have come to accept my lowered expectations of myself."

A related explanation, similarly negative, is that women with children

99. On the problem of the male traits and preferences setting the standards for judging conduct, see the writings of Catharine MacKinnon. See especially her essay on women as lawyers in Feminism Unmodified 70-77 (1987). In the Michigan survey, when asked in an open-ended question what was the most important way, if any, that being a woman had advantaged them in their careers, many women said it had not advantaged them at all. $A$ larger number said that they had been advantaged by traits that they considered especially found in women, such as compassion. Even larger numbers, however, listed advantages that suggested accepting and capitalizing on the male-dominated nature of the bar. A large number of women regarded as the principal advantage of their gender that they had stood out from the men around them and been noticed, mostly by men. Others reported that their greatest advantage was that men did not know what to expect from them and were surprised, to the men's disadvantage, when they acted aggressively.

100. Nearly all report "some" discrimination; very few report "a lot." Those who report some discrimination are as satisfied with their careers as those who report none.

101. Many more of the Michigan women report having begun law school with a desire to work in government, legal services, or some other "public interest" setting.

102. One woman, hearing our findings, suggested that the mothers who said they were satisfied had probably just taken their daily dose of valium. 
are satisfied with less because, to an even greater degree than women in general, they anticipate and adjust to discrimination in their careers. Under this view, if women with children expect employers to relegate them to marginal careers or to reject them altogether ${ }^{103}$ (and if they accept the values of a system that would permit such marginalization), ${ }^{104}$ they may be content with less, and especially content when they find that they are subjected to no greater discrimination than other women. ${ }^{105}$

In large part, however, these explanations for the satisfaction of women with children seem unduly negative. What these explanations miss is the possibility that the hypothesis about the satisfactions of multiple roles is correct-that many women with children say that they are especially satisfied with their careers because they really have something to feel especially good about. Their days are extremely busy, but they are succeeding simultaneously in several important spheres in their lives. They enjoy their family lives. They enjoy their jobs. And to the extent that each causes stress, each also provides respite from the other. ${ }^{106}$ They may well be coming as close as any group of women in American society to "having it all."

The Michigan women with children have been in an unusually auspicious position for attaining success in the multiple spheres of their lives. As we have already seen, almost none of the women with children were single and the great majority earned, together with their spouse or living partner, a very high family income. ${ }^{107}$ Eighty percent of the women with children were married to attorneys, other professionals, or business owners or managers. We have no information about these women's child-care ar-

103. In an ABA survey conducted in May 1983, attorneys were asked about "weaknesses" of women as attorneys. The most frequently perceived weakness was their familial responsibilities and familial conflicts. See Winter, "Women Lauyers Work Harder, Are Paid Less, But They're Happy," 69 ABA J. 1384, 1387 (1983). In the Michigan survey, only a few women expressed a belief that they had experienced especially adverse treatment because of pregnancy or parenting, but we asked no direct question about such treatment. One woman said, "I have taken three medical leaves for pregnancy-related disabilities. For career purposes, it would have been less detrimental to have suffered three heart attacks." One of the men in explaining why he thought fewer women worked in firms responded, "There is a practical, built-in bias in the smaller firms against women in that childbearing causes an interruption in work and smaller firms have a . . great financial investment in any new addition."

104. Some researchers of job satisfaction argue that many workers who might feel anger at their working conditions do not feel anger because they (often irrationally) accept blame for their circumstances. See Crosby, Deprivation, 7, 28, $63-66$ (cited in note 25).

105. Like women in general, women with children have reported themselves experiencing discriminatory treatment at some points from other lawyers, judges, and clients, but women with children have experienced such treatment no more frequently than other women.

106. One mother, for example, thought that her family responsibilities were her greatest career advantage as a woman: "The family demands help you keep perspective on what is important." See additional statements on p. 266 supra.

107. See supra pp. 263-65. 
rangements, but, with their family incomes, they could generally have afforded care of high quality.

The Michigan women with children also had more opportunity than most working people in our society to be selective about the jobs they took. Lawyers have more choices than most people, and the Michigan graduates had, in general, a greater range of jobs to choose among than the graduates of most schools. In picking their jobs, a high proportion of the Michigan mothers seem to have deliberately chosen settings in which they believed they could sustain a rational balance of their family and professional lives. Many seem to have avoided or left private practice because they believed it would place extraordinary demands on their time. And some of those who chose private practice report having sought and selected firms where their needs as parents were recognized and accepted.

A further and final explanation for the comparatively high satisfaction of the Michigan women with children may simply be that they have gone ahead and let the other shoe drop. The women in these classes are now in their mid- and late thirties. Women with professional careers rarely find a "perfect" moment in their careers to bear children. These women have had children anyway and found the satisfactions substantial. It is easy sometimes to forget how much pleasure children can bring. The women probably anticipated with foreboding the difficulties of balancing child care with work and, although they have found the difficulties formidable, the difficulties may well have proven less formidable than they had feared. ${ }^{108}$

These competing explanations for the high expressed satisfactions of women with children-second best accepted or first best proclaimedcannot be easily tested empirically with our data. Except for a small group who say they work part time, the women with children work long hours, spend equal time with men on various lawyering activities (such as litigation), engage as frequently in outside activities, and report equally high levels of stress within their work setting. As such, their high reported satisfaction is, sad to say, consistent both with an especially beleaguered group who remain positive in the face of overwhelming demands and with a group who are doing as much as everyone else and pulling it off. To untangle these explanations, we might have engaged in an investigation of the quality of their day-to-day lives that did not depend entirely on selfreports and that involved imposing our own standards about what ought to be considered satisfying. We did not do so.

My own inclination to accept the reports of high satisfaction of the women with children at face value rests in part on the objective reasons

108. Conversely, men with children may be less prepared for the difficulties posed by the conflicting demands of family and children and may find the task of balancing more onerous than they had expected. 
why these women with children might feel good about their lives: in this country, it seems a bit odd to doubt people who are so rich when they say they are contented. It also rests on my reluctance to credit suggestions that women with children are any less able than women without children or than men with or without children to appraise the quality of their lives rationally.

\section{LIMITS AND SOME CONCLUDING COMMENTS}

Here are three limitations on the reach of our findings, limits that may suggest some of the agenda for future research.

The first is that the Michigan surveys measured career satisfaction at only two points not long after law school -5 years after and 7 to 10 years after. We cannot be certain that the women with children will continue to express high satisfaction over the years to come. Many of the Michigan women with children who had taken leaves expressed high satisfaction at the time of our last survey, but feared that their deviations from full-time work might eventually harm their careers. They may be proven right. Our smaller samples of Michigan women in the 1970-73 classes who have now been out of law school 15 years may or may not prove an accurate guide. Like the women 5 years out, these earlier graduates were much more likely than their male classmates to work in settings other than private practice. ${ }^{109}$ And, like the women 5 years out, the full-time working women 15 years out were as satisfied as their male classmates with their careers overall and with the balance of their family and professional lives, and the women with children expressed as high satisfactions as the women without. ${ }^{110}$ On the other hand, although the women in the 15-year classes had very high earned incomes, they earned much less than men (about $63 \%)$, even after the types of settings they worked in were taken into account. $^{111}$ If the women in the classes of 1976-79 earn only $63 \%$ as much

109. Our respondents from the classes of 1970-73 included 53 full-time working women and 903 full-time working men. Of this group, $49 \%$ of the women and $67 \%$ of the men were in private practice 15 years after graduation.

110. For the classes of $1970-79$ after 15 years, $51 \%$ of women and $42 \%$ of men were quite satisfied with the balance of their family and professional lives and $67 \%$ of women and $62 \%$ of men were quite satisfied with their careers overall (categories 1 and 2 on the 7-point scale. Differences not significant). There were also no significant differences between the satisfaction levels of women with and women without children. Throughout the history of our surveys, the 15-year classes have reported higher levels of career satisfaction than the 5 year classes. Compare the results of the 5-year survey in table 5.

111. The full-time working women in these classes earned on average $\$ 77,600$ as opposed to $\$ 124,100$ for the men. Among those in private practice, the full-time working women averaged $\$ 91,700$, the full-time working men $\$ 143,300$. Women's and men's total family incomes were, however, closely similar-an average of $\$ 157,500$ for all full-time women and $\$ 151,500$ for all full-time men. Full-time working women with children earned no 
as the men in the same classes when they have been out of law school for 15 years, it is uncertain how satisfied they will feel. They may well have higher expectations than their predecessors. ${ }^{112}$

The second note of caution about the reach of our findings regards later classes of lawyers, the classes after the classes of 1979. Are times changing for the more recent graduates? The results of the five-year surveys of the classes of 1980 and 1981 are reported from place to place in this article. The results of the five-year surveys of the classes of 1982 and 1983 became available just as this article went to press. On the surface, satisfaction levels seem to have changed only a little. The full-time working women in these four later classes are as satisfied as men with their careers overall and with the balance of work and family, and the mothers are as satisfied as the nonmothers, and all are as satisfied as the women and men in the classes on which we have been reporting. No longer are mothers more satisfied than other groups, but they are fully as satisfied.

One important pattern is different in the more recent classes-a difference in the settings in which women are choosing to work. Over the years since 1979, there has been a fairly steady increase in the proportion of women entering private practice and an even greater increase in the proportion of both women and men entering large firms. ${ }^{113}$ The gap between the proportion of women and the proportion of men working in private practice is closing swiftly. ${ }^{114}$ This trend is significant for our purposes because it has been in the firms in general and the largest firms in particular that women and men have consistently reported the lowest satisfaction with the balance between their private and professional lives. ${ }^{115}$ With the increase of women in private practice, the numbers of women who are dissatisfied with the balance is increasing. ${ }^{116}$

less on average than full-time working women without children. Thus, the lower average earnings of women are not due to especially truncated careers of the women with children.

112. None of the women in the classes of 1972 and 1973 took first jobs in large firms after law school. Many of the women in the classes of 1976-79 did so. A major change in the policies of the large firms with regard to the hiring of women seems to have occurred in the years between 1973 and 1976.

113. Five years after graduation, $22 \%$ of the women in the $1976-79$ classes were working in law firms with more than 50 lawyers. For the classes of 1980 and 1981, the proportion had risen to $32 \%$ and for the classes of 1982 and 1983 , to $39 \%$. For men, across the same three time periods, the proportion working in large firms five years after graduation was $27 \%$ for the 1976-79 classes, $36 \%$ for the 1980-81 classes, and 44 percent for the 1982-83 classes. At least for first placements after law school, this is a pattern repeated by the recent graduates of many other schools.

114. In the 1976-79 classes five years after graduation, $44 \%$ of women and $70 \%$ of men worked in private firms. See table 1 supra. In the 1982-83 classes five years after graduation, $59 \%$ of women and $71 \%$ of men were in private practice.

115. See supra notes 71 and 81 .

116. In the more recent classes, women and men in private practice (and particularly large firm private practice) remain substantially less satisfied with the balance of their family and professional lives than men and women working in other settings. Thus, as the proportion working in private practice increases, the average levels of satisfaction decrease. For 
The final note of caution is one we have sounded before. Whatever our conclusions about the women graduating from Michigan, we must be cautious about offering any guesses about the probable situation for women lawyers who are graduates of other schools. The survey by the American Bar Association of young private practitioners reveals much dissatisfaction among women with their jobs. ${ }^{117}$ Although the ABA survey did not explore whether women's dissatisfaction was related to the conflicting demands of practice and family, its findings about job satisfaction in general make it quite uncertain whether the findings of the Michigan study could be replicated for the graduates of other schools who have different resources, aspirations, and opportunities. ${ }^{118}$

Fifty years ago, 30 even, nearly all lawyers were men. They married, and their wives stayed home and raised children. The wives contributed to their husbands' careers by providing emotional support, by freeing their husbands to concentrate on making money, and by entertaining their husband's clients and co-workers. During the 1970s, the same sorts of women who had been the preceding generations' homemakers entered the legal profession in large numbers. During the same period, men were encouraged to participate more actively than had the earlier generations of fathers in the upbringing of their children.

The entry of women into the profession might conceivably, at least imaginably, have led to a fundamental restructuring of the work of lawyers. Everyone, the daydream runs, would work fewer hours so that everyone could have rich family and rich professional lives. Of course, that did not happen. What did happen, at least as illustrated by the Michigan women, is that women without children have adapted to working as long hours and under the same stresses that men always have and that men with and without children have continued to work in the same old ways.

Only women with children (and only some of them) have worked to fashion an accommodation. Most of the Michigan women with children have worked part time or taken leaves from work for at least some period and have apparently found that the profession will accommodate them to this extent. But the women with children who work full time, and the great majority do, typically work very long hours. In large numbers, they too have adapted to the draining work schedules of men, while almost no men have adapted to the family-oriented behavior of women. Most women (and men) seem to accept as a fact of life that the successful practice

example, the proportion of women who are dissatisfied (categories 5,6 , and 7) with the balance of their family and professional lives has increased from $18 \%$ of the women in the classes of 1976-79 up to $29 \%$ of the women in the classes of 1980-81 and up to $33 \%$ of the women in the classes of 1982-83. The decline in satisfaction has occurred for women with and women without children.

117. See p. 258 supra.

118. See note 50 supra. 
of law demands huge amounts of time and emotional energy and that women with children will expend such time and energy at work and then again when they come home. In the answers to our surveys, women do not speak of the structure of the profession as inherently sexist. They are often distraught at the demands, but they rarely complain about men or "the system" creating a profession that demands 60-hour work weeks for success, a system that, given men's resistance to child care, forces women who enter the profession to choose either to forgo having children or to become unfulfilled parents.

The paradox this article has explored has been that, despite the double burdens that women with children bear, the Michigan women we studied are well satisfied with their careers and generally satisfied with the balance of work and family. Some people, it appears, enjoy the triathalon. Some people like scaling mountains carrying babies on their backs. We need, nonetheless, to remember that even though the women with children are comparatively satisfied, the young lawyers we surveyed, men and women, are less satisfied with the balances of their family and professional lives than they are with any other aspect of their careers. And our most recent surveys indicate that satisfaction with the balance is declining. A question with which we are left is whether there will ever come a point, as more women reach positions of power in the profession, when women and then men will seek in large numbers to achieve other, more fully satisfying balances. 